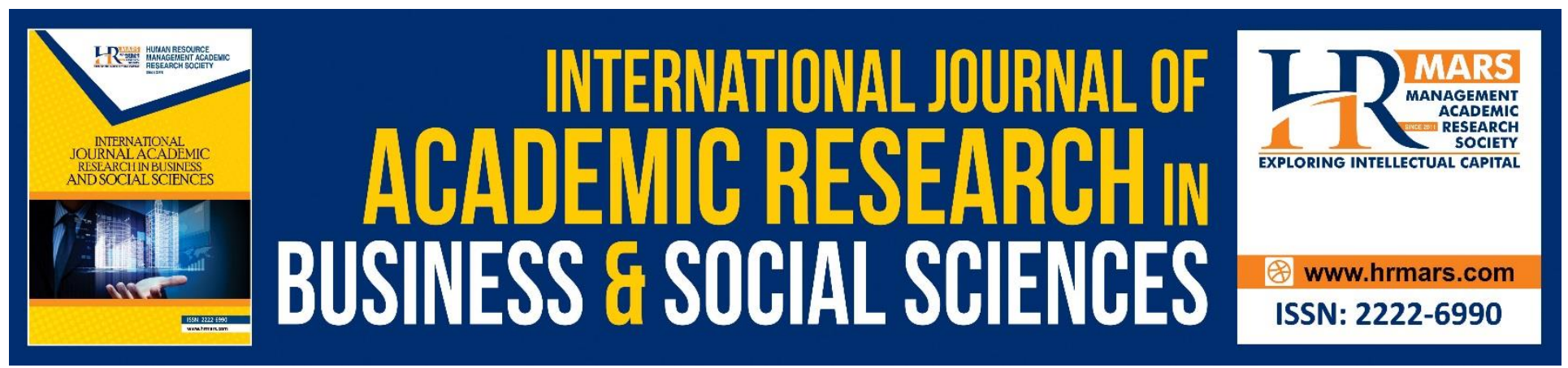

\title{
The Moderation Effect of Pay Transparency for the Relationship between Justice Judgments and Intrinsic Motivation
}

Kaze Ella Joelle

To Link this Article: http://dx.doi.org/10.6007/IJARBSS/v8-i12/5018

DOI: $10.6007 /$ IJARBSS/v8-i12/5018

Received: 17 Nov 2018, Revised: 07 Dec 2018, Accepted: 21 Dec 2018

Published Online: 23 Dec 2018

In-Text Citation: (Joelle, 2018)

To Cite this Article: Joelle, K. E. (2018). The Moderation Effect of Pay Transparency for the Relationship between Justice Judgments and Intrinsic Motivation. International Journal of Academic Research in Business and Social Sciences, 8(12), 361-376.

Copyright: (C) 2018 The Author(s)

Published by Human Resource Management Academic Research Society (www.hrmars.com)

This article is published under the Creative Commons Attribution (CC BY 4.0) license. Anyone may reproduce, distribute, translate and create derivative works of this article (for both commercial and non-commercial purposes), subject to full attribution to the original publication and authors. The full terms of this license may be seen at: $\underline{\text { http://creativecommons.org/licences/by/4.0/legalcode }}$

Vol. 8, No. 12, 2018, Pg. 361 - 376

http://hrmars.com/index.php/pages/detail/IJARBSS

JOURNAL HOMEPAGE

Full Terms \& Conditions of access and use can be found at http://hrmars.com/index.php/pages/detail/publication-ethics 


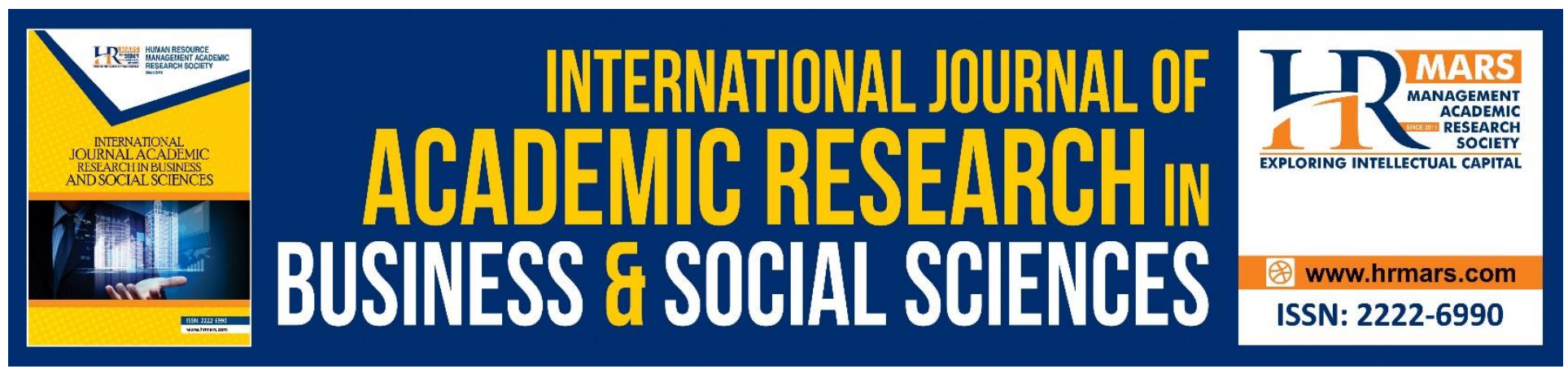

\title{
The Moderation Effect of Pay Transparency for the Relationship between Justice Judgments and Intrinsic Motivation
}

\author{
Kaze Ella Joelle \\ College of Economics and management, Nanjing University of Aeronautics and Astronautics, \\ Nanjing, China \\ Email: Kazeella@gmail.com
}

\begin{abstract}
The fairness of managerial pay can be judged in terms of its distributive justice properties and its procedural justice properties. While both types of justice have been studied extensively in the organizational literature, their relative importance in predicting work-related outcomes is still open to debate. In this paper, we provide field evidence that the relationship between pay justice and managers' intrinsic motivation is moderated by pay transparency, which is the extent to which managers know each other's pay levels. In a homogeneous sample of Brundi's bank managers, we find that procedural justice is a better predictor of intrinsic motivation when pay transparency is low, and that distributive justice is a better predictor of intrinsic motivation when pay transparency is high. These findings that are congruent with fairness heuristic theory suggest the importance of considering pay transparency for understanding and designing fair managerial pay systems.

Keywords: Fairness heuristic theory; distributive justice; pay transparency; intrinsic motivation; procedural justice

\section{Introduction}

An organization cannot construct an effective team of working professionals without good Human Resources whereas effective management of human resources is necessary for any organization to achieve high performance. This is true in every organization where performance is constantly scrutinized by a variety of stakeholders. In an atmosphere of fiscal constraint, it's imperative that organizations accomplish their missions as efficiently and efficiently as possible. Motivation represents a key element of employee performance and productivity, making it a central part of human resource management (Coggburn et al., 2010). Motivation and ability together determine individual performance (Baer, 2012). Fortunately, both can be influenced externally by proper management.
\end{abstract}


Work motivation is an important topic for scholars and managers alike because of its effect on performance in the workplace. Research on work motivation has many practical applications pertaining to specific work-related behaviors such as: accepting a job with a particular organization (entry decision); showing up for work each day (attendance or absenteeism); being on-time or late for work (punctuality or tardiness); following supervisory orders (obedience); working hard or goofing off (level of work effort); inventing new ways to perform on the job (creativity); staying with an organization (commitment); and deciding to retire or resign (exit decision). The study of work motivation helps scholars identify and understand factors that motivate individual performance, while simultaneously providing managers with practical ways of influencing employee performance in order to achieve organizational goals. Despite years of study, no single, unifying theory of work motivation can account for the wide range of behavior found in the workplace. Since people are motivated by a variety of needs (Berman, 2006; Pinder, 2008), work motivation theories are multifaceted - encompassing factors that are inherent to individuals (intrinsic), related to external circumstances (extrinsic), and pertaining to social interactions (interpersonal).

A number of studies have been conducted that have highlighted the importance of fair treatment of organizational participants, as it has been observed that fairness has positive effects on work-related outcomes such as motivation (Bradford, Quinton, Myhill, \& Porter, 2014; Cho \& Dansereau, 2010; Khan, Farooq, \& Ullah, 2010). Literature also proposes that fairness of compensation is a vital element of employees' motivation that they receive against their organizational input (Nix \& Wolfe, 2016; Novac \& Bratanov, 2014). Distributional justice and procedural justice have gained importance by researchers in this regard. While other numerous studies used various research tools in different applications such as (Mohsin, Rasheed, \& Saidur, 2018) and (Mohsin, Zhou, Iqbal, \& Shah, 2018).

The main purpose of this research is to advance our understanding of intrinsic work motivation by distributive justice and procedural justice. Such an analysis is important since these two concepts of justice are intrinsically different, and therefore have different implications for our understanding of pay systems fairness and our ability to design and operate pay systems. In this paper, we study the relative importance of two kinds of justice by their effect on managers' intrinsic motivation, which is an important and desired consequence of organizational fairness.

Our analysis provides the following contributions to the literature. First, we attempt to address a fundamental question in the organizational justice literature, concerning the relative importance of PJU and DJU in explaining work-related outcomes, within the context of managerial compensation. Second, in doing so, we challenge this literature's overwhelming focus on PJU (e.g. Lau and Buckland 2001; Erdogan 2002; Lau and Shohilin 2005), introducing pay transparency as a necessary condition for DJU judgments. Third, in addition to the theoretical analysis by Collela et al. (2007), we demonstrate that pay transparency and justice interact to affect motivation, rather than having a direct effect. Finally, we complement experimental evidence on the fairness heuristic effect by providing field evidence on the relative importance of PJU and DJU.

\section{Literature Review}

Previous studies shows different findings in this line of research but this study will analyze the relative importance of DJU and procedural justice PJU of the pay system in predicting managerial intrinsic motivation of Brundi commercial banks. Therefore, descriptive research design and quantitative 
research methods will be used in this study. Quantitative research is a means for testing theories to find relationships between variables via statistical procedures. A quantitative approach will be taken, in which surveys will be used to collect data. Survey research presents numeric explanations of developments or attitudes within a population by studying a sample population. Data will be collected from the sample with the purpose of making assertions regarding the entire population. The road map of research is as follows:

i) The literature will be reviewed to explore the area of study.

ii) Questionnaires will be formed and will be reviewed by experts to assess its length and understandability.

iii) Data will be collected from different banks.

iv) Data will be analyzed using different statistical techniques in SPSS.

v) Results of the study will be presented.

vi) Conclusions and recommendations will be provided

The purpose of this literature review is to provide recent research that highlights the influence of pay fairness on employees' intrinsic motivation and the moderation of pay transparency in this relationship. Extensive-based review of the literature is carried out on pay fairness and intrinsic motivation in order to provide a foundation for current study. Pay fairness is considered to have positive impact on work-linked outcomes such as motivation (Cerasoli, Nicklin, \& Ford, 2014; Fang \& Gerhart, 2012; Gerhart \& Fang, 2015; Hartmann \& Slapničar, 2012; van Knippenberg \& De Cremer, 2008). The most suitable way to understand this is to review the work of motivational scholars and theorists such as fairness heuristic theory (BOS \& ALLAN LIND, 2004; Lind, Kray, \& Thompson, 2001). Theories on pay fairness are typically drawn from psychology and economics (Lambright, 2010). Many studies have been conducted by researchers in the field of organizational fairness that have stressed on the significance of fair treatment of organizational employees, as fairness has positive impact on work-related outcomes like motivation (Bakhshi, Kumar, \& Rani, 2009; Hassan, 2013; Leblebici, 2012; Rai, 2013; Zoghbi-Manrique-de-Lara \& Suárez-Acosta, 2014). An important element of organizational participants' motivation is the fairness of compensation they receive in exchange for their organizational contribution (Bacha \& Walker, 2013; Meng \& Wu, 2015; Rasch \& Szypko, 2013). Productivity and performance of an organization depends upon the organizational commitment of its employees and their motivation (Bushra, Ahmad, \& Naveed, 2011). As good leadership has been proposed as one of the most decisive factors contributing to the attitudes of employees toward their organization (Ciulla, 2012), fair leader taking care of employees is probably among the most prominent predictors of organizational commitment.

Literature on organizational fairness has shown that insights of fairness are deeply related to the employee's attitudes, such as satisfaction at work and his/her commitment (Clinebell, Skudiene, Trijonyte, \& Reardon, 2013; Mohammad, Quoquab Habib, \& Alias, 2011; Strom, Sears, \& Kelly, 2014). Fairness definitions have been broadly applied in many theoretical issues and researches. Organizational fairness refers to people's perceptions of fairness in organizations along with their associated behavioral, cognitive and emotional reactions (Greenberg, 2011). Fairness is considered to include two elements: distributive justice and procedural justice (McDowall \& Fletcher, 2004). Distributive justice relates to the preoccupations expressed by employees considering the distribution of outcomes and resources (Miller, 2017; Nozick, 2017). Procedural justice refers to the 
INTERNATIONAL JOURNAL OF ACADEMIC RESEARCH IN BUSINESS AND SOCIAL SCIENCES Vol. 8, No. 12, Dec, 2018, E-ISSN: 2222-6990 @ 2018 HRMARS

fairness of procedures used to define the outcome of decisions. Those procedures should be coherent, unprejudiced and morally acceptable (Tyler \& Blader, 2013).

Procedural justice research started in 1975, when Thibaut and Walker's seminal work was published, which compared the Anglo-American adversarial legal system to the European inquisitorial system. (Blodgett, Hill, \& Tax, 1997) found that because the adversarial system allows the disputants process control-or voice-during the presentation of evidence, it was seen as more fair than the inquisitorial system. In laboratory studies, participants deemed a process to be fair when they had a voice in the process, even though the outcome derived from the process was not desirable to them. This suggests that fairness evaluation of a procedure depends on having opportunities to exercise voice during procedures (Mohsin, Zhou, et al., 2018) and (Mohsin, Rasheed, et al., 2018).

The ability for employees to find out what other employees in their workplace make is called pay transparency. Pay transparency is an important factor in contemporary discussions about pay fairness, and is argued to enhance pay justice (Colella, Paetzold, Zardkoohi, \& Wesson, 2007). However, pay transparency has received only marginal empirical attention in the performance evaluation literature thus far, which may be explained by this literature's preoccupation with the procedural fairness of performance evaluation systems (Lau \& Moser, 2008). Based on fairness heuristic theory, we predict that when employees know each other's pay levels, and are therefore able to compare each other's pay-to-effort ratios, distributive justice will become relatively more important in affecting motivation. In contrast, when employees do not know each other's pay levels, and are unable to judge distributive justice, they will predominantly refer to procedures to judge the fairness of their pay.

Job satisfaction has been one of the most studied variables over the last decades of organizational research. Interest in job satisfaction derives from its relationships to other organizational outcomes including organizational commitment, absenteeism, turnover and performance. Job satisfaction has been defined and measured both as a global construct and as a concept with multiple dimensions or facets (Azanza, Moriano, \& Molero, 2013). Job satisfaction implies a positive affect resulting from the appraisal of one's job or job experiences (Eslami \& Gharakhani, 2012).

One of the most often cited definitions on job satisfaction is thr one given by Spector according to whom job satisfaction has to do with the way how people feel about their job and its various aspects. It has to do with the extent to which people like or dislike their job. That's why job satisfaction and job dissatisfaction can appear in any given work situation. Job satisfaction represents a combination of positive or negative feelings that workers have towards their work. Meanwhile, when a worker employed in a business organization brings with it the needs, desires and experiences which determinate expectations that he has dismissed. Job satisfaction represents the extent to which expectations are and match the real awards. Job satisfaction is closely linked to that individual's behavior in the work place (Davis et al.,1985).

Organizational commitment can be thought of as the extent to which employees are dedicated to their organization and are willing to work to its benefit, and the prospect that they will maintain membership (Sušanj \& Jakopec, 2012). Meyer and Allen (1991) indicated three correlated but distinguished dimensions of organizational commitment: affective, continuance and normative commitment. Affective commitment represents an employee's emotional attachment, identification 
INTERNATIONAL JOURNAL OF ACADEMIC RESEARCH IN BUSINESS AND SOCIAL SCIENCES Vol. 8, No. 12, Dec, 2018, E-ISSN: 2222-6990 @ 2018 HRMARS

and involvement in the organization. Continuance commitment is commitment based on costs that an employee associates with leaving the organization, while normative commitment represents employee's feeling of the obligation to stay within the organization. Organizational commitment not only increases the success in a certain role, but also encourages the individual to achieve many voluntary actions necessary for organizational life and to reduce the absenteeism rate, turnover ratio and enhances the organization productivity (Jernigan, Beggs, \& Kohut, 2016).

O'Reilly and Chatman (1986) see organizational commitment as a psychological attachment to an organization. According to Ruokolainen (2011) it reflects "the degree to which employee internalizes or adopts the characteristics or perspectives of the organization". Commitment can be formed by three independent mechanisms: compliance, identification and internalization. Compliance is shallowest of them all and is connected to rewards. Person adopts certain attitudes and behaviors in order to gain specific awards. Identification is step further into deeper commitment. Employee feels proud to be part of that specific organization and thus accepts and respects its' values and accomplishments. He or she wants to establish or maintain good relationship with that specific group. However, what separates that from the internalization is that he or she does not adapt those values as his or her own. Therefore, internalization occurs finally when there is value congruence between the person and the organization. Employee accepts organization's values because those are very similar to his or her own. (O'Reilly \& Chatman 1986). The fact that this model was first one to make clear distinction between the instrumental exchange and psychological attachment as forms of commitment has been noted as benefit for this model. Instrumental refers to commitment based on rewarding, while psychological attachment is the deeper form (Sokoll, 2014).

However, there have been few matters that have received critique in this model. Internalization and identification correlate positively with intend to stay with an organization, while compliance acts in the opposite way actually correlating positively with turnover. This is further shown in the results implicating that the longer the tenure, the less likely it is that commitment is based on compliance. (O'Reilly \& Chatman 1986, 495.) Since it is often thought that organizational commitment reduces the likelihood of turnover, there has been questioning whether compliance can be thought as a form of organizational commitment at all (Meyer \& Herscovitch 2001). Another point that has received critique in this model is that internalization and identification come very close to each other as concepts, and even include some of the same elements (see Meyer \& Herscovitch 2001). In the studies conducted later it has actually been proved that internalization and identification can be merged together forming one dimension. The measures correlate very highly with one another and other variables show quite similar patterns of correlations with these two dimensions. (Caldwell, Chatman \& O'Reilly 1990) For these reasons, this model never has been that largely used and Allen and Mayer's model became dominantly used in the studies of commitment (Weibo, Kaur \& Jun 2010) Outcomes associated with organizational fairness include intrinsic motivation, job satisfaction, job performance, employee withdrawal behaviors (i.e., absenteeism, turnover), counterproductive work behavior (e.g., employee theft), organizational commitment, and organizational citizenship behavior (Choi \& Rainey, 2014). Two meta-analysis studies found that distributive justice and procedural justice were all associated with many of the outcomes listed above (Cohen-Charash \& Spector, 2001; Colquitt et al., 2001). Associations were in predicted directions: high levels of organizational fairness predict high intrinsic motivation, job satisfaction, high performance, low withdrawal, fewer 
INTERNATIONAL JOURNAL OF ACADEMIC RESEARCH IN BUSINESS AND SOCIAL SCIENCES

Vol. 8, No. 12, Dec, 2018, E-ISSN: 2222-6990 @ 2018 HRMARS

counterproductive behaviors, high organizational commitment, and more organizational citizenship behaviors.

Based on the review of literature done in section given above, hypotheses of our study are given below:

$\mathrm{H} 1$ : Procedural justice is more strongly associated with intrinsic motivation than distributive justice when pay transparency is low.

$\mathrm{H} 2$ : distributive justice is more strongly associated with intrinsic motivation than procedural justice when pay transparency is high.

In addition to the two hypotheses, we expect a strong correlation between procedural justice and distributive justice in conformity with extant evidence on the fair process effect (e.g. Collie et al. 2002). Since we expect that pay transparency is a condition for the occurrence of effects of distributive justice on intrinsic motivation, we expect no direct effect of pay transparency on either procedural justice or distributive justice.

\section{Data and Method \\ Data Collection}

Data collection, both primary and secondary, is an important part of the research process. Having identified your sources of data, advises systematically collecting the data in sufficient quality and quantity in order to conduct your data analysis. So if the researcher does not collect and gather the appropriate data, they will not meet their research aims and objectives sufficiently enough to produce credible and thorough findings. As already mentioned, in collecting primary research for this study, the researcher will use semi-structured interviews and refer to secondary data from the literature review.

\section{Sample of Study}

In this study a survey has been conducted consist of 179 middle managers of commercial banks of Brundi In order to test the proposed hypothesis. We meet the managers of all banks of Brundi and request them to make participation in performance appraisal studies and to provide the feedback on the impact of their performance appraisal system actions. The managers of twelve banks agreed to take participation in the survey, which is $80 \%$ of the banking market of Brundi. Each bank's HR manager will provide us with a list of all middle managers and their email addresses in the bank.

The total number of selected managers in this study were 280 of all 18 banks and the in charge of the division were the 2 nd hierarchical level managers. While the in-charge of both departments and branches were the 3rd hierarchical level with an average age 45 years and with an average 6 years of experience on the current position and also these managers had on average 35 subordinates. One of the department managers was their median hierarchical level. Contingent on the structure and the size of the organization, the number of participants in the survey varies from 4 to 28 from each of the bank. The questioner was sent through e-mails to all respondents with the request to take part in the survey because the survey is totally based on web. 
INTERNATIONAL JOURNAL OF ACADEMIC RESEARCH IN BUSINESS AND SOCIAL SCIENCES

Vol. 8, No. 12, Dec, 2018, E-ISSN: 2222-6990 @ 2018 HRMARS

\section{Selection of Variables}

The variables used in this study are distributive justice (DJU), Procedural justice (PJU), intrinsic motivation (MOT), and pay transparency (TR). In this study the variable distributive justice (DJU) is measured with a mechanism developed by (Leventhal, 1980) and recently its validity was confirmed by (Colquitt, Conlon, Wesson, Porter, \& Ng, 2001). The second variable is the procedural justice (PJU) which is calculated as the fairness of the three components of a compensation system based on performance. Hence the questioner is designed to ask the respondents to specify how much they believe the payment system, the goal setting and performance measurement contribute to the fair determination of their compensation. We chose a simple approach that reflects the complete fairness perception, instead of questions related to the fair processes attributes. Due to such things as "consistency" and "accuracy", an overly standard picture is provided that illustrates what should be considered a "fair" system (Colquitt et al., 2001; Lind \& Tyler, 1988). Our study also allows for a better difference between DJU and PJU.

In addition, the intrinsic motivation inventory is used in this study in order to measure the intrinsic motivation (Vallerand, 1997). The tool is used to assess the extent to which a person enjoys work and perceives their intellectual challenges interests and excitement (Kuvaas, Buch, Weibel, Dysvik, \& Nerstad, 2017), (Houkes, Janssen, de Jonge, \& Nijhuis, 2001). For example "The activities at my work are exciting and challenging to do" (Hartmann \& Slapničar, 2012).

We select the project used for each of these three variables to analyze the model by assessing their item loading on the underlying construction. When the loading items exceed or met the benchmark of o0.71 then the items retained (Gefen, Straub, Boudreau, Gefen, \& Straub, 2000). While the pay Transparency (TR) the moderator variable moderator is calculated with four items (Cronbach a $0.859)$, for instance item is "what other managers get paid i know exactly".

We use a simple average of those four indicators to form an overall pay Transparency score and also control for the potential effect of bonus, hierarchical position and tenure, all of which may affect justice perception and intrinsic motivation. Tenure is basically the number years in the current position. The employs with longer tenure lengths are familiar with the assessment system and may have more knowledge about the rewards of others. Also a scale is used to measure the Hierarchical position in the organization that indicates the manager position in the bank for instance divisional manager=1, unit manager=2, department manager=3, branch manager $=4$ and other managerial position=5. Here Hierarchical position is used as the proxy for actual pay due to the sensitivity of disclosure. The level of compensation (pay) may have an impact on the sensitivity of DJU and also we segregate the internal influence of DJU on intrinsic motivation from extrinsic motivation. Bonuses captures the satisfaction effect and is calculated as the ratio of actual obtained bonus to maximum potential bonus.

\section{Analysis}

The partial least squares method and the structural equation model (SEM) is applied in this study to evaluated and test the proposed hypothesis and also variance and covariance method of SEM is preferred, if the sample size is modest (F. Hair Jr, Sarstedt, Hopkins, \& G. Kuppelwieser, 2014; Götz, Liehr-Gobbers, \& Krafft, 2010). The moderation effect is proposed in this study to test the hypotheses by investigating the differences in coefficients between subgroups (Hartmann \& 
INTERNATIONAL JOURNAL OF ACADEMIC RESEARCH IN BUSINESS AND SOCIAL SCIENCES

Vol. 8, No. 12, Dec, 2018, E-ISSN: 2222-6990 @ 2018 HRMARS

Slapničar, 2012). The subgroups are modeled as low Transparency and high Transparency based on the average score of the manipulated variable TR and also to establish the independence of our observations from the 12 banks, this study test the ANOVA one way analysis of variance for the variables that scores might reproduce the organizational as an alternative of individual variance (Anderson, 2001).

\section{Results and Discussion}

Table 1 presents the descriptive statistics of all the selected variables including Mean, Median and standard deviation. The variables DJU, PJU, MOT and TR are calculated on the basis of likred scale from 1 to 5 such as 1 indicates the lowest and 5 denotes the highest. In this study the mean (3.03) of variable DJU has been measured as comparatively high, the mean (2.85) of PJU is to some extent lower, comparatively the mean of MOT is 3.92. While the mean (1.93) of TR is relatively measured low for the banking sector. Also the actual bonus of managers is observed 58 percent of their prospective bonus. The variable MOT (3.80) in the low Transparency subgroup is higher comparatively than the high Transparency subgroup 3.80 which is find slightly yet significant. Also in the high and low Transparency subgroups we did not find the difference between the variables DJU and PJU. That means that pay Transparency does not affect their level, but rather their subsequent impact on our hypothetical motivations see (Gerhart, Rynes, \& Fulmer, 2009).

Table 1 Descriptive statistics of the selected variables.

\begin{tabular}{|c|c|c|c|c|c|c|c|}
\hline & & & & Transparency & & & Std. \\
\hline & Mean & Median & SD & Subgroup & Mean & SD & mean \\
\hline DJU & 4.13 & 4 & 0.948 & Low & 3.78 & 0.98 & 0.124 \\
\hline & & & & High & 4.12 & 0.78 & 0.199 \\
\hline PJU & 3.95 & 4 & 0.778 & Low & 3.56 & 0.78 & 0.2 \\
\hline & & & & High & 3.78 & 0.89 & 0.085 \\
\hline MOT & 4.94 & 5 & 0.678 & Low & $5.34 * * *$ & 0.55 & 0.084 \\
\hline & & & & High & $3.80 * * *$ & 0.45 & 0.081 \\
\hline TRA & 2.85 & 3 & 0.889 & Low & $2.28 * * *$ & 0.67 & 0.025 \\
\hline & & & & High & $3.65 * * *$ & 0.88 & 0.086 \\
\hline BON & 0.58 & 0.92 & 0.473 & Low & 0.84 & 0.34 & 0.076 \\
\hline & & & & High & 0.69 & 0.6 & 0.056 \\
\hline TEN & 5.66 & 4.55 & 5.74 & Low & 5.97 & 6.78 & 0.735 \\
\hline & & & & High & 5.54 & 4.98 & 0.543 \\
\hline HIE & 3.83 & 3 & 2.251 & Low & 3.34 & 2.4 & 0.25 \\
\hline & & & & High & 3.76 & 2.32 & 0.246 \\
\hline
\end{tabular}

$* * * p<0.05$, indicates significant difference.

As table 2 represents the results of the measurement model, for the calculation of selected model there is no inclusive fit statistics for the assessment of the model quality, concerning reliability of the individual item, reliability construction and validity of discriminant and convergent for our reflective hypotheses is simplified through a number of partial statistics see (Till \& Karren, 2011). The measurement model results are described as the loading factor 0.71 means sufficient individual item 
INTERNATIONAL JOURNAL OF ACADEMIC RESEARCH IN BUSINESS AND SOCIAL SCIENCES Vol. 8, No. 12, Dec, 2018, E-ISSN: 2222-6990 @ 2018 HRMARS

reliability in their respective construction, this result suggest that variance more than 50 percent in the observed variables are shared with the construct (Wetzels, Odekerken-Schröder, \& van Oppen, 2009). Where the table 3 shows the estimated model quality criteria and The Dillon Goldstein $\rho$ which is a measure of construct reliability or internal consistency for all variables DJU, PJU and MOT is above 0.75 and the study of (Templeton, Lewis, \& Snyder, 2002) supports our results. Although the constructs discrimination validity is presented in Tables 2 and 3 which is evaluated by AVE that signifies the shared average variance between a construct and its indicators and on other constructs by cross loadings of items (Grewal, Cote, \& Baumgartner, 2004).

Both tables demonstrate acceptable discriminant the construct validity. Unsurprisingly, the correlation amongst the variables DJU and PJU is highly significant and positive, but there is both constructs can be evocatively distinguished. The variable TR which is moderating variable its reliability was recognized by calculating the Cronbach $\alpha$ of the four items.

Table 2 Cross loadings (full sample, $\mathrm{n}=179$ )

\begin{tabular}{lllllll}
\hline & DJU & PJU & MOT & BON & HIE & TEN \\
\hline DJU1 & 0.843 & 0.607 & 0.204 & 0.070 & 0.013 & -0.056 \\
DJU 2 & 0.825 & 0.678 & 0.304 & -0.034 & -0.026 & 0.078 \\
DJU 3 & 0.734 & 0.67 & 0.154 & -0.044 & 0.211 & -0.077 \\
PJU1 & 0.435 & 0.689 & 0.244 & -0.088 & -0.057 & -0.198 \\
PJU 2 & 0.587 & 0.706 & 0.334 & 0.075 & -0.088 & -0.344 \\
RJU 3 & 0.236 & 0.786 & 0.013 & 0.045 & -0.213 & -0.287 \\
MOT1 & 0.346 & 0.411 & 0.725 & -0.321 & -0.199 & 0.475 \\
MOT2 & 0.150 & 0.209 & 0.687 & -0.211 & -0.127 & 0.312 \\
MOT3 & 0.067 & 0.219 & 0.927 & -0.187 & -0.123 & 0.213 \\
Bon & 0.023 & 0.067 & -0.313 & 0.991 & 0.145 & 0.016 \\
Hier & 0.043 & -0.087 & -0.263 & 0.099 & 0.169 & -0.075 \\
Ten & -0.089 & -0.061 & 0.183 & 0.025 & -0.012 & 0.759 \\
\hline
\end{tabular}

Table 3. The results of variables related to high and low transparency.

\begin{tabular}{llllll}
\hline & AVE & Comp. reliability $(\mathrm{r})$ & $\mathrm{R}^{2}$ & Cronbach $(\boldsymbol{\alpha})$ & Redundancy $\mathrm{Q}^{2}$ \\
\hline High transparency $(\mathrm{n}=95)$ & & & & \\
DJU & 0.458 & 0.861 & 0.584 & 0.745 & 0.007 \\
PJU & 0.487 & 0.657 & 0.093 & 0.951 & 0.024 \\
MOT & 0.923 & 0.934 & 0.333 & 0.761 & 0.086 \\
BON & n.a & n.a & n.a & n.a & n.a \\
HIER & n.a & n.a & n.a & n.a & n.a \\
TEN & n.a & n.a & n.a & n.a & n.a \\
Low transparency & $(\mathrm{n}=84)$ & & & & \\
DJU & 0.954 & 0.876 & 0.845 & 0.815 & 0.001 \\
PJU & 0.843 & 0.348 & 0.951 & 0.945 & 0.084 \\
MOT & 0.842 & 0.643 & 0.129 & 0.335 & 0.117 \\
BON & n.a & n.a & n.a & n.a & n.a \\
HIER & n.a & n.a & n.a & n.a & n.a \\
TEN & n.a & n.a & n.a & n.a & n.a \\
\hline
\end{tabular}


INTERNATIONAL JOURNAL OF ACADEMIC RESEARCH IN BUSINESS AND SOCIAL SCIENCES

Vol. 8, No. 12, Dec, 2018, E-ISSN: 2222-6990 @ 2018 HRMARS

Table 4 Correlation matrix and discriminant validity coefficients $(n=179)$.

\begin{tabular}{llllllll}
\hline & HIER & TEN & BON & TRA & DJU & PJU & MOT \\
\hline HIER 2.73 (1.215) & n.a & & & & & & \\
TEN 4.76 (4.730) & -0.245 & n.a & & & & & \\
BON 0.68 (0.462) & 0.108 & 0.017 & n.a & & & & \\
TRA 1.93 (0.839) & -0.063 & -0.056 & 0.076 & n.a & & & \\
DJU 3.03 (0.939) & -0.014 & 0.078 & 0.036 & -0.076 & 0.974 & & \\
PJU 2.85 (0.787) & -0.067 & -0.034 & 0.085 & -0.085 & $0.537^{* *}$ & 0.864 & \\
& & & & - & & & \\
MOT 3.92 (0.659) & $-0.134^{*}$ & 0.090 & -0.317 & $0.274 *$ & 0.155 & $0.192 *$ & 0.747 \\
\hline
\end{tabular}

* Significant at 0.05 level two tailed; ** significant at 0.01 level two tailed and n.a, is non-applicable. Off-diagonal elements are the correlations among constructs. Diagonal elements are the square root of the variance shared between the constructs and their indicators (AVE). For discriminant validity, diagonal elements should be larger than off-diagonal elements. Next to variable names means and SD (in parenthesis) are presented.

The path estimation results are summarized in the table 3 and 5 . We measured the statistical parameter estimates significance with replacements by using a bootstrap procedure. While the parameter Predictive validity estimates was evaluated with the Stone Geisser Q2 test or a cross validated redundancy index. The results shows that the model has extrapolative relevance if the value of Q2 for all latent variables is greater than 0 , which can show that the model have predictive relevance. Similarly the goodness of fit statistics are measured by PLS models such as covariance and variance based on structural equation model and the maximum likelihood estimation method (MLSEM). It is believed that in addition to the reliability and validity of the construction, the explanatory variance of all constructs and the importance of positive $Q 2$ provide sufficient evidence of model fitting. 
INTERNATIONAL JOURNAL OF ACADEMIC RESEARCH IN BUSINESS AND SOCIAL SCIENCES

Vol. 8, No. 12, Dec, 2018, E-ISSN: 2222-6990 @ 2018 HRMARS

Table 5 analysis of subgroup.

\begin{tabular}{|c|c|c|c|c|c|c|c|}
\hline & \multicolumn{3}{|c|}{ Low transparency $(n=64)$} & \multicolumn{3}{|c|}{ High transparency $(\mathrm{n}=75)$} & \multirow[b]{2}{*}{$\begin{array}{l}\text { Path } \\
\text { difference }\end{array}$} \\
\hline & Original sample & $\begin{array}{l}\text { Sample } \\
\text { mean }\end{array}$ & SE & $\begin{array}{l}\text { Original } \\
\text { sample }\end{array}$ & $\begin{array}{l}\text { Sample } \\
\text { mean }\end{array}$ & SE & \\
\hline DJU-MOT & -0.476 & -0.834 & 0.162 & $0.675^{* *}$ & $0.435 * *$ & 0.154 & $0.035 * * *$ \\
\hline PJU- DJU & $0.213^{* *}$ & $0.444 * *$ & 0.185 & $0.872 * * *$ & $0.892 * * *$ & 0.095 & $-0.86 * * *$ \\
\hline PJU- MOT & $0.786 * *$ & $0.745^{* *}$ & 0.139 & -0.083 & -0.925 & 0.245 & $0.52 * * *$ \\
\hline BON-DJU & 0.056 & 0.253 & 0.341 & -0.089 & -0.664 & 0.089 & $0.03 * *$ \\
\hline BON- MOT & -0.244 & -0.269 & 0.672 & $-0.320 * * *$ & $-0.755^{* * *}$ & 0.086 & $0.04^{* *}$ \\
\hline BON- PJU & -0.748 & -0.853 & 0.742 & 0.079 & 0.084 & 0.124 & $-0.17 * *$ \\
\hline HIER- DJU & 0.082 & 0.099 & 0.742 & 0.055 & 0.012 & 0.077 & 0.067 \\
\hline HIER-MOT & -0.131 & -0.132 & 0.378 & $-0.322 * * *$ & $-0.982 * * *$ & 0.076 & $0.60 * * *$ \\
\hline HIER-PJU & -0.063 & -0.853 & 0.362 & -0.173 & -0.276 & 0.202 & $0.20 * *$ \\
\hline TEN- DJU & 0.476 & 0.888 & 0.356 & -.0969 & 0.230 & 0.101 & $-0.14 * *$ \\
\hline TENURE- MOT & -0.827 & -0.043 & 0.111 & -0.085 & 0.0432 & 0.034 & $-0.04 * *$ \\
\hline TENURE- PJU & 0.893 & 0.052 & 0.301 & -0.305 & -0.892 & 0.116 & $0.23 * * *$ \\
\hline
\end{tabular}

Two-tailed test, D.F. $=179, * * p<0.01, * * * p<0.001$ and the coefficients of corresponding path are associated by the following test

If information on outcomes of other managers is not available than the variable PJU is more strongly associated with intrinsic Motivation. We recommend that if it has this information than the variable DJU be more strongly linked to Motivation. The results from these predictions confirms that the relationship amongst the variables MOT and PJU is significant and positive in the low Transparency subgroup that are $0.316, p<0.01$. The results shows that there is no relationship between MOT and PJU, but we find reverse in the high Transparency subgroup. While in this subgroup the path coefficient that is $0.332, p<0.01$ from DJU to MOT is significantly higher. Although almost insignificant and zero coefficient $(-0.095)$ in the low Transparency subgroup. The difference amongst the coefficients is significant $(p<0.001)$ and its amount is 0.420 . Also the results shows no relationship amongst the variables intrinsic Motivation and PJU in the high pay Transparency subgroup and its amount is -0.086 which is non-significant. Moreover between the low and high Transparency subgroups, there is significantly difference between the coefficients for the relationship amongst the variables PJU and MOT and its value is $-0.414, p<0.001$. Additionally, significant and positive relationship has to be found between the both subgroup variables DJU and PJU. This is reliable with the available evidence. However, we also found that this relationship in the high Transparency subgroup is significantly stronger than the low Transparency subgroup and its value is $0.394, p<0.001$.

Whenever the information about pay level is available than the two types of justice are more strongly related. It mean that the fair process effect of the low-pay Transparency subgroup complements the fair outcome effect of the high-pay Transparency subgroup. Since our cross sectional data did not determine the direction of the latter effect, we reanalyze the model of the inverse relationship between the two kinds of justice. It provides results of similar quality. We also tested whether we correctly expected no direct effect of pay Transparency on either PJU or DJU. As 
INTERNATIONAL JOURNAL OF ACADEMIC RESEARCH IN BUSINESS AND SOCIAL SCIENCES Vol. 8, No. 12, Dec, 2018, E-ISSN: 2222-6990 @ 2018 HRMARS

expected, we find coefficients near zero for the relationships between pay Transparency and both PJU and its value is -0.135 , n.a and DJU value is 0.085 , n.a. Results of an alternative model in which we exclude all control variables are almost the same. Overall, our findings confirm the validity of the explored model and the role of pay Transparency as a moderator of the relationships between PJU and DJU and intrinsic Motivation.

\section{Conclusions}

Our analysis on fairness heuristic theory, which concerns the impact of information availability on justice judgments. We argued and showed that the level of pay Transparency affects the relative importance of procedural and distributive fairness in predicting intrinsic Motivation. The results of our analyses indicate that when managers do not know other managers' compensation levels, PJU is the only predictor of intrinsic Motivation. Under low pay Transparency, PJU plays a significantly more important role in forming justice judgments, than under a high pay Transparency regime. When pay Transparency is higher, which means that information about peers' outcomes becomes available, the perception of DJU becomes a more important predictor of intrinsic Motivation. Overall, it appears that when pay Transparency increases, the relative importance of the two kinds of justice reverses. These findings provide support for fairness heuristic logic (as well as for the relevance of pay Transparency. They also show that DJU matters for intrinsic Motivation and that it matters even more than PJU if information on other people's pay is available. While in the low Transparency subgroup control variables (bonus, hierarchical position and tenure) have no significant effect in the model, it is interesting that in the high Transparency subgroup where managers have more cues about other managers' bonuses and pay, the attainment of bonus is found to be negatively related to intrinsic Motivation. The same effect is found for hierarchical level as a proxy for pay level. This controversial result has been intensively reported in the literature. The negative effects are outweighed by the perception of distributive fairness and its positive impact on intrinsic Motivation.

Our results further support our contention that the predictions of fairness heuristic theory can also be tested in field settings. In combination with the experimental results on Transparency, we feel that our field evidence has added to the rigor of the original theory. Justice effects, consistent with fairness heuristic logic, do not only occur as a consequence of purposely designed manipulations, but also exist in real settings. Of course, when considered on its own, our study has limitations that are attributable to the method of data gathering and data analysis. The typical limitations of survey studies that depend on perceptual measurement and self-reports potentially also limit the validity our findings. However, we believe that the care by which we organized the survey and the high response rates guarantee that the results in the study cannot only be explained by random or systematic measurement error. The limitations of the cross-sectional analysis do not allow us to infer causal relationships. In combination with the experimental results on Transparency, we believe, however, that our field evidence has added to the validity of the original theory.

\section{Reference}

Azanza, G., Moriano, J. A., \& Molero, F. (2013). Authentic leadership and organizational culture as drivers of employees' job satisfaction. Revista de Psicología del Trabajo y de las Organizaciones, 29(2), 45-50. 
INTERNATIONAL JOURNAL OF ACADEMIC RESEARCH IN BUSINESS AND SOCIAL SCIENCES Vol. 8, No. 12, Dec, 2018, E-ISSN: 2222-6990 @ 2018 HRMARS

Bacha, E., \& Walker, S. (2013). The relationship between transformational leadership and followers' perceptions of fairness. Journal of Business Ethics, 116(3), 667-680.

Baer, M. (2012). Putting creativity to work: The implementation of creative ideas in organizations. Academy of Management Journal, 55(5), 1102-1119.

Bakhshi, A., Kumar, K., \& Rani, E. (2009). Organizational justice perceptions as predictor of job satisfaction and organization commitment. International journal of Business and Management, 4(9), 145.

Bell, R., \& Martin, J. (2012). The relevance of scientific management and equity theory in everyday managerial communication situations.

Ben-Ner, A. (2013). Preferences and organization structure: Toward behavioral economics microfoundations of organizational analysis. The Journal of Socio-Economics, 46, 87-96.

Bradford, B., Quinton, P., Myhill, A., \& Porter, G. (2014). Why do 'the law'comply? Procedural justice, group identification and officer Motivation in police organizations. European Journal of Criminology, 11(1), 110-131.

Bushra, F., Ahmad, U., \& Naveed, A. (2011). Effect of transformational leadership on employees' job satisfaction and organizational commitment in banking sector of Lahore (Pakistan). International journal of Business and Social science, 2(18).

Cappelen, A. W., Eichele, T., Hugdahl, K., Specht, K., Sørensen, E. Ø., \& Tungodden, B. (2014). Equity theory and fair inequality: a neuroeconomic study. Proceedings of the National Academy of Sciences, 111(43), 15368-15372.

Cerasoli, C. P., Nicklin, J. M., \& Ford, M. T. (2014). Intrinsic Motivation and extrinsic incentives jointly predict performance: A 40-year meta-analysis. Psychological bulletin, 140(4), 980.

Cho, J., \& Dansereau, F. (2010). Are transformational leaders fair? A multi-level study of transformational leadership, justice perceptions, and organizational citizenship behaviors. The Leadership Quarterly, 21(3), 409-421.

Choi, S., \& Rainey, H. G. (2014). Organizational fairness and diversity management in public organizations: Does fairness matter in managing diversity? Review of Public Personnel Administration, 34(4), 307-331.

Ciulla, J. B. (2012). Ethics effectiveness: the nature of good leadership.

Clinebell, S., Skudiene, V., Trijonyte, R., \& Reardon, J. (2013). Impact of leadership styles on employee organizational commitment. Journal of Service Science (Online), 6(1), 139.

Coggburn, J. D., Battaglio Jr, R. P., Bowman, J. S., Condrey, S. E., Goodman, D., \& West, J. P. (2010). State government human resource professionals' commitment to employment at will. The American Review of Public Administration, 40(2), 189-208.

Colella, A., Paetzold, R. L., Zardkoohi, A., \& Wesson, M. J. (2007). Exposing pay secrecy. Academy of Management Review, 32(1), 55-71.

Eslami, J., \& Gharakhani, D. (2012). Organizational commitment and job satisfaction. ARPN Journal of Science and Technology, 2(2), 85-91.

Fang, M., \& Gerhart, B. (2012). Does pay for performance diminish intrinsic interest? The International journal of human resource management, 23(6), 1176-1196. 
INTERNATIONAL JOURNAL OF ACADEMIC RESEARCH IN BUSINESS AND SOCIAL SCIENCES Vol. 8, No. 12, Dec, 2018, E-ISSN: 2222-6990 @ 2018 HRMARS

Gerhart, B., \& Fang, M. (2015). Pay, intrinsic Motivation, extrinsic Motivation, performance, and creativity in the workplace: Revisiting long-held beliefs. Annu. Rev. Organ. Psychol. Organ. Behav., 2(1), 489-521.

Greenberg, J. (2011). Organizational justice: The dynamics of fairness in the workplace. APA handbook of industrial and organizational psychology, 3, 271-327.

Hartmann, F., \& Slapničar, S. (2012). Pay fairness and intrinsic Motivation: the role of pay Transparency. The International journal of human resource management, 23(20), 42834300.

Hassan, S. (2013). Does fair treatment in the workplace matter? An assessment of organizational fairness and employee outcomes in government. The American Review of Public Administration, 43(5), 539-557.

Jernigan, E., Beggs, J. M., \& Kohut, G. F. (2016). AN EXAMINATION OF NURSES'WORK ENVIRONMENT AND ORGANIZATIONAL COMMITMENT. Academy of Educational Leadership Journal, 20(1), 112.

Khan, K. U., Farooq, S. U., \& Ullah, M. I. (2010). The relationship between rewards and employee Motivation in commercial banks of Pakistan. Research journal of international studies, 14, 37-52.

Kont, K.-R., \& Jantson, S. (2013). Division of labor and coordination, intra-organizational career and salary fairness: Study in Estonian university libraries. Library Management, 34(6/7), 415-432.

Lambright, K. T. (2010). An update of a classic: Applying expectancy theory to understand contracted provider Motivation. Administration \& Society, 42(4), 375-403.

Lau, C. M., \& Moser, A. (2008). Behavioral effects of nonfinancial performance measures: The role of procedural fairness. Behavioral Research in Accounting, 20(2), 55-71.

Leblebici, D. (2012). Impact of workplace quality on employee's productivity: case study of a bank in Turkey. Journal of Business Economics and Finance, 1(1), 38-49.

Lee, H.-W., \& Lin, M.-C. (2014). A study of salary satisfaction and job enthusiasm-Mediating effects of psychological contract. Applied Financial Economics, 24(24), 1577-1583.

Lepper, M. R., \& Greene, D. (2015). The hidden costs of reward: New perspectives on the psychology of human Motivation: Psychology Press.

McDowall, A., \& Fletcher, C. (2004). Employee development: an organizational justice perspective. Personnel review, 33(1), 8-29.

McKinney, W. R., Mulvaney, M. A., \& Grodsky, R. (2013). The development of a model for the distribution of merit pay increase monies for municipal agencies: A case study. Public Personnel Management, 42(3), 471-492.

Meng, F., \& Wu, J. (2015). Merit pay fairness, leader-member exchange, and job engagement: Evidence from Mainland China. Review of Public Personnel Administration, 35(1), 47-69.

Miller, D. (2017). Distributive justice: What the people think Distributive Justice (pp. 135-173): Routledge.

Mohammad, J., Quoquab Habib, F., \& Alias, M. A. (2011). Job Satisfaction and Organisational Citizenship Behaviour: an Empirical Study at Higher Learning Institutions. Asian Academy of Management Journal, 16(2).

Mohsin, M., Rasheed, A. K., \& Saidur, R. (2018). Economic viability and production capacity of wind 
INTERNATIONAL JOURNAL OF ACADEMIC RESEARCH IN BUSINESS AND SOCIAL SCIENCES Vol. 8, No. 12, Dec, 2018, E-ISSN: 2222-6990 C 2018 HRMARS

generated renewable hydrogen. International Journal of Hydrogen Energy, 43(5), 2621-2630. https://doi.org/10.1016/j.ijhydene.2017.12.113

Mohsin, M., Zhou, P., Iqbal, N., \& Shah, S. A. A. (2018). Assessing oil supply security of South Asia. Energy, 155, 438-447. https://doi.org/10.1016/j.energy.2018.04.116

Moorman, R. H., \& Byrne, Z. S. (2013). How Does Organizational justice Afiect Organizational Citizenship Behavior? Handbook of organizational justice, 355.

Morand, D. A., \& Merriman, K. K. (2012). "Equality theory" as a counterbalance to equity theory in human resource management. Journal of Business Ethics, 111(1), 133-144.

Nozick, R. (2017). Distributive justice Distributive Justice (pp. 3-61): Routledge.

Rai, G. S. (2013). Impact of organizational justice on satisfaction, commitment and turnover intention: Can fair treatment by organizations make a difference in their workers' attitudes and behaviors? Journal of Human Sciences, 10(2), 260-284.

Rasch, R., \& Szypko, M. (2013). Perception is reality: The importance of pay fairness to employees and organizations. WorldatWork Journal Q, 3, 2013.

Sokoll, S. (2014). Servant leadership and employee commitment to a supervisor. International Journal of Leadership Studies, 8(2), 88-104.

Strom, D. L., Sears, K. L., \& Kelly, K. M. (2014). Work engagement: The roles of organizational justice and leadership style in predicting engagement among employees. Journal of Leadership \& Organizational Studies, 21(1), 71-82.

Suma, S., \& Lesha, J. (2013). Job satisfaction and organizational commitment: The case of Shkodra municipality. European Scientific Journal, ESJ, 9(17).

Sušanj, Z., \& Jakopec, A. (2012). Fairness perceptions and job satisfaction as mediators of the relationship between leadership style and organizational commitment. Psihologijske teme, 21(3), 509-526.

Tyler, T., \& Blader, S. (2013). Cooperation in groups: Procedural justice, social identity, and behavioral engagement: Routledge.

van Knippenberg, D., \& De Cremer, D. (2008). Leadership and fairness: Taking stock and looking ahead. European Journal of Work and Organizational Psychology, 17(2), 173-179.

Zoghbi-Manrique-de-Lara, P., \& Suárez-Acosta, M. A. (2014). Employees' reactions to peers' unfair treatment by supervisors: The role of ethical leadership. Journal of Business Ethics, 122(4), 537-549. 